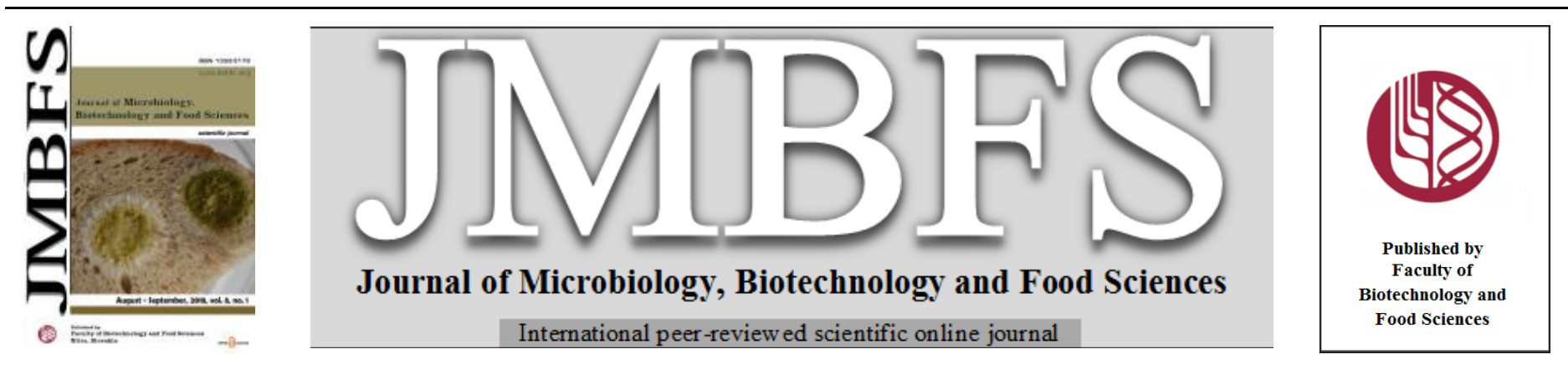

\title{
CHARACTERIZATION OF MORINGA OLEIFERA LEAVES AND ITS UTILIZATION AS VALUE ADDED INGREDIENT IN UNLEAVENED FLAT BREAD (CHAPATTI)
}

\author{
Bilal Sajid Mushtaq ${ }^{1}$, Imran Pasha ${ }^{1}$, Rabia Omer ${ }^{2}$, Muhammad Bilal Hussain $^{3}$, Tabassum Tufail ${ }^{3}$, Mohammad Ali Shariati ${ }^{4}$, Anna A. \\ Derkanosova ${ }^{5}$, Irina P. Shchetilina, Nadezhda N. Popova, Evgenij S. Popov ${ }^{8}$, Olga V. Oseneva, Denis V. Kharitonov ${ }^{10}$
}

Address(es):

${ }^{1}$ National Institute of Food Science and Technology, University of Agriculture Faisalabad, Pakistan

${ }^{2}$ Department of Food Science and Human Nutrition, University of veterinary and Animal Sciences Lahore, Pakistan

${ }^{3}$ Institute of Home and Food Sciences, Government College University Faisalabad

${ }^{4}$ Laboratory of Biocontrol and Antimicrobial Resistance, Orel State University named after I.S. Turgenev, Orel, 302026, Russia, +7(4862) 751-318.

${ }^{5}$ Candidate of Technical Sciences, associate professor, service and restaurant business department, Voronezh state university of engineering technologies, Voronezh, 394036, Russia.

${ }^{6}$ Candidate of Technical Sciences, associate professor, service and restaurant business department department, Voronezh state university of engineering technologies,

Voronezh, 394036, Russia.

${ }^{7}$ Candidate of Chemistry Sciences, associate professor, service and restaurant business department department, Voronezh state university of engineering technologies, Voronezh, 394036, Russia.

${ }^{8}$ Doctor of Technical Sciences, associate professor, service and restaurant business department department, Voronezh state university of engineering technologies, Voronezh, 394036, Russia.

${ }^{9}$ Candidate of Economic Sciences, associate professor, trade and commodity research department, Voronezh state university of engineering technologies, Voronezh, 394036, Russia.

${ }^{10}$ Student, Department of Technology of Products of Animal Origin, Voronezh state university of engineering technologies, Voronezh, 394036, Russia.

*Corresponding author: itsmee1919@gmail.com

doi: 10.15414/jmbfs.2018.8.1.751-755

\section{ARTICLE INFO}

Received 4. 6. 2018

Revised 29. 6. 2018

Accepted 4. 7. 2018

Published 1. 8. 2018

Regular article oPEN 2 ACcess

\begin{abstract}
Micronutrient deficiency is a major concern now a days as more than 30 percent of world's population is suffering from nutritional deficiency. People are getting awareness regarding food biodiversity, therefore they demand value added and nutritionally enriched food products to counter appetite as well as to improve their health. This study was conducted to assess the nutritional potential of Moringa oleifera leaves powder (MOLP) and a product was developed to ensure its efficient utilization in chapatti (Unleavened flat bread). For this purpose proximate composition was analyzed for both moringa oleifera leaves powder and whole wheat flour (WWF). The depicted results for MOLP were as $10.75 \%$ moisture, $7.79 \%$ ash, $6.49 \%$ crude fat, $23.72 \%$ crude protein, $12.48 \%$ crude fiber. Afterward, raw materials were analyzed for mineral profile, MOLP showed better mineral content as; $1295 \mathrm{mg} / 100 \mathrm{~g} \mathrm{~K}, 211.92 \mathrm{mg} / 100 \mathrm{~g} \mathrm{Mg}, 6.32$ $\mathrm{mg} / 100 \mathrm{~g} \mathrm{Cu}, 7.37 \mathrm{mg} / 100 \mathrm{~g} \mathrm{Fe}, 12.83 \mathrm{mg} / 100 \mathrm{~g} \mathrm{Na}, 6.3 \mathrm{mg} / 100 \mathrm{~g} \mathrm{Zn}$ and $8.67 \mathrm{mg} / 100 \mathrm{~g} \mathrm{Mn}$, as compared to WWF. Then antioxidant activity of both materials was analyzed and again MOLP showed better results as compared to WWF. The recorded values for Total Phenolic Content (TPC), Total Flavonoid Content (TFC) and antioxidant activity of MOLP were as; $88.63 \mathrm{mg} \mathrm{GAE} / \mathrm{g}, 30.86 \mathrm{mg}$ CE/g and $89.27 \%$, respectively. Furthermore composite flour blend was prepared with the addition of 5, 10, 15 and 20\% MOLP in WWF and analyzed for pasting properties then chapattis ware developed and analyzed for mineral profile and antioxidant activity as well as sensory attributes. It was observed that chapatti with $20 \%$ MOLP contained highest level of minerals as; $286.07 \mathrm{mg} / 100 \mathrm{~g} \mathrm{~K}, 147.75$ $\mathrm{mg} / 100 \mathrm{~g} \mathrm{Mg}, 5.12 \mathrm{mg} / 100 \mathrm{~g} \mathrm{Cu}, 4.09 \mathrm{mg} / 100 \mathrm{~g} \mathrm{Fe}, 12.83 \mathrm{mg} / 100 \mathrm{~g} \mathrm{Na}, 4.78 \mathrm{mg} / 100 \mathrm{~g} \mathrm{Zn}$ and $5.78 \mathrm{mg} / 100 \mathrm{~g} \mathrm{Mn}$. Similarly the treatment with highest proportion of MOLP showed maximum antioxidant activity; TPC, TFC and DPPH depicted results $8.83 \mathrm{mg}$ GAE/g Extract, $3.66 \mathrm{mg} \mathrm{CE} / \mathrm{g}$ of extract, $80.52 \%$ respectively. The sensory evaluation of chapatti exhibited that treatments which had 5 and $10 \%$ of MOLP demonstrated comparatively better results with overall acceptability scores 6.90 and 6.20 , respectively, however $\mathrm{T}_{2}(10 \%$ MOLP) was the best acceptable combination regarding its sensorial attributes. Conclusively the micronutrient profile and antioxidant activity of chapattis gradually enhanced by increasing the level of MOLP.
\end{abstract}

Keywords: Micronutrient, food biodiversity, Moringa oleifera, chapatti, Antioxidant activity, pasting properties

\section{INTRODUCTION}

Nowadays consumers are getting more conscious about their eating habits and giving consideration towards nutritionally enriched food either by plant or animal origin. Everyone needs specific amounts of certain nutrients to maintain and regulate the body functions. Plants are great source of micro nutrients, Moringa oleifera is a miracle tree belongs to moringaceae family having 13 different species and one genera only (Mahmood $\boldsymbol{e t}$ al., 2010). It is a native tree of sub Himalayan region, it is now native in many part of the world like Arabia, South east Asia, Africa, the pacific and Arabian islands and south America. It has different names in different regions like Shigru in Sanskrit, Sohanjna in Punjabi. Sanja in Bangli and Drumstick tree or horseradish tree an English. (Anwar and
Bhanger, 2003). Moringa is widely known and consumed in these regions along with other vegetables due to its outstanding nutritional profile. It is rich source of micro and macro nutrients. It has earned its Name as "miracle tree" due to its phenomenal healing ability for different diseases including some chronic diseases (Mouminah, 2015). Every part of this miracle plant can be used as food and it is believed to be the most useful plant (Rebecca et al., 2006).

Moringa oleifera contains more vitamin C than oranges, higher concentration of vitamin A than carrots, higher calcium content than milk and more potassium than bananas. Moreover, there is 9 times more iron in moringa than spinach, 4 times more fiber than oat and the protein quality resembles egg and milk protein having more digestibility and assimilation (Mahmood et al., 2010). The fruits, pods, leaves, flowers and of this plant are rich in nutrition and are utilized as 
vegetable. Moringa leaves and fruit are valuable source of vitamins, beta carotene, protein, calcium, phosphorus and antioxidants. The antioxidants include ascorbic acids, flavonoids, and phenolic compounds. In Philippine moringa is considered as a best friend of mothers it results in tremendous increase in milk production of lactating women. It's all parts; leaves, fruits root, gum, bark, seed, flower and seed oil are being used for cure of different ailments i.e. inflammation, cardiovascular, intestinal, hematological and anti-fever. The seeds of Moringa exhibit antimicrobial activity and are acrid in taste. Flowers of the Moringa contain nine essential amino acids, wax quercetin, glucose and sucrose (Anwar et al., 2007).

The therapeutic properties of the moringa oleifera have been attributed to high concentrations of phytochemicals in it; moringa is used for medication purpose in different regions of world. It is most widely consumed for the patients of diabetes and hyper tension (Mbikay, 2012). Moringa also contains appreciable amount of phenolic compounds, therefore, it proves a good source of antioxidant (Siddhuraju and Becker, 2003). In addition, it also act as myocardial preservatives and anti-peroxidative, therefore, it is used therapeutically against cardiovascular problems (Nandave et al., 2009). Leaves of moringa oleifera possess a considerable amount of crude protein and fiber, therefore, these can be used for different nutritious purposes in the form of either fresh or extract (Owusu et al., 2008).

Pakistan is one of those country in which chapatti (Flat bread) is preferably consumed to fulfil the nutritional and caloric requirements. Wheat produced in Pakistan is mainly used for the production of chapatti (Anjum et al., 2002). It is prepared in different traditional forms like; parathas, tandoori nans, sada roti and poories (Butt et al., 1997). Due to certain micronutrients' deficiency in whea these bakery products can be fortified with other nutrient enriched natura ingredients to meet the therapeutic and nutritional needs of consumers. To boost up mineral and protein level of chapatti it has been being fortified with different legumes, leafy vegetables and plant leaves. They are good source of vitamins, minerals, fibers and complex carbohydrates. Therefore, chapattis are being fortified with different kind of natural plant based fortificant to rectify differen kind of nutrition related maladies its consideration is important post effects of fortification on various properties of chapatti (Iqbal and Bhanger, 2006) Number of studies have been reported on the addition of green leafy vegetables in different bakery items to increase their nutritional profile Singh and Kawatra (2006) reported that iron and $\beta$-carotene in biscuits, pakora, and cake is increased as the amaranths leaves are added. Extract of amla and moringa leaves were used in the biscuits and the antioxidants of biscuits increased up to the mark (Reddy $\boldsymbol{e}$ $\boldsymbol{a l}, \mathbf{2 0 0 5}$ ). The objective of these studies were to increase the nutritional value of the product. The current study was aimed to characterize the dried moringa leaves for its nutrition and its application in chapatti (Flat bread) as valuable ingredient

\section{MATERIAL AND METHODS}

Moringa oliefera leaves were procured from the Crop Physiology Department, University of Agriculture Faisalabad. Whole wheat flour and reagents were procured from the local market.

\section{Preparation of Sample}

Moringa leaves were washed and dried under shade at 25C-30C, after prope drying leaves were grounded into fine powder and kept at $25 \mathrm{C}$ into airtight container for further use.

\section{Proximate Analysis}

Moringa oleifera leaves (MOLP) and whole wheat flour (WWF) were analyzed for Moisture, Ash, Crude Fat, Crude Fiber and Crude Protein following the methods described in (AOAC, 2006)

\section{Mineral Analysis}

Moringa leaves powder, whole wheat flour and moringa leaves supplemented chapattis were analyzed for their mineral content using wet digestion method the quantification was done by using Atomic Absorption Spectroscopy AAS (Mode AA240 Varian K, Australia). The quantification of Sodium (Na) and Potassium (K) was done by using Flame photometer (Sherwood Flame Photometer 410, Cambridge, UK), following the methods as described in (AOAC, 2006).

\section{Determination of Total Phenolic (TPC)}

Methanolic extraction was done for TPC determination of samples and estimated by Folin- Ciocalteu Assay following the method described by Sun et al. (2007). Absorbance was checked by UV-Vis spectrophotometer (IRMECO Germany) at $760 \mathrm{~nm}$. All the samples were taken in triplicate and the same protocol was followed for the replications. Total phenolic contents were calculated by the calibration curve plotted between different concentrations of Gallic acid

\section{Determination of Total Flavonoid Content (TFC)}

Total Flavonoid Content estimated using the method described by Kim et al (2006). Same methanolic extract was used as used for TPC. Absorbance of the mixture was measured at $415 \mathrm{~nm}$ by using UV spectrophotometer (IRMECO Germany). The absorbance of blank involving distilled water and reagents was also taken in the similar manner. By using catechin as a standard, calibration curve was plotted between concentrations versus absorbance. Hence the tota flavonoid content was calculated as mg catechin equivalent (CE) per gram of the extract

\section{Determination of Scavenging Activity against 1, 1-Dipheny-2-Picry- Hydrazyl (DPPH) Radical}

The antioxidant activity was determined using the DPPH spectrophotometric method described by Mensor et al. (2001). Absorbance was measured at $515 \mathrm{~nm}$. DPPH solution was used as control. Percentage antioxidant activity was calculated by using this formula.

$$
\text { Total Antioxidant activity DPPH }(\%)=\frac{A \text { control }- \text { A sample }}{\text { A control }} \times 100
$$

$\mathrm{A}_{\text {control }}$ : Absorbance f control mixture

$\mathrm{A}_{\text {sample }}$ : Absorbance of the sample mixture

\section{Preparation of Composite flour blends for Chapattis (Flat Bread)}

Premix was prepared by fortifying wheat flour with moringa leaves powder. Ratio of premix was as 95:05, 90:10, 85:15, 80:20 and denoted as $\mathrm{T}_{1}$ to $\mathrm{T}_{4}$. Whole wheat flour used as control sample

\section{Pasting properties Composite flour blends}

Above prepared blends were analyzed for their pasting properties using a Rapid Visco Analyzers RVA-4 in accordance to the method No. 76-21.01 of AACC (2000).

\section{Preparation Moringa leaves supplemented Chapattis}

Chapattis were prepared with all composite flour blends following the procedure described by Kadam et al. (2012) with slightly modification. Blend consist of $100 \%$ whole wheat flour used as control sample.

\section{Sensory Evaluation}

Sensory evaluation of moringa leaves powder supplemented chapattis was done for different attributes like taste, flavor, chew ability, foldability and overall acceptability by semi trained judges using 9-point hedonic scale described by Meilgaard et al., (2007).

\section{Statistical Analysis}

Results obtained from all parameters were then statistically analyzed. All analysis was carried out in triplicate and the data was reported as means \pm standard deviation. Significant difference among treatments was evaluated through analysis of variance (ANOVA) under complete randomized design (CRD) applied according to the method described by Steel $\boldsymbol{e t}$ al. (1997).

\section{RESULTS AND DISCUSSION}

Data presented in Table (1) exhibited the proximate composition of Whole Whea flour and Moringa oleifera Leaves powder. The data obtained from the research work showed that Whole wheat flour (WWF) contained $1.75 \%$ moisture, $13.84 \%$ protein, 1.42 crude fat, $1.67 \%$ crude fiber and $1.70 \%$ Ash content on the other hand, dried moringa leaves (MOLP) contained higher content as compared to whole Wheat flour as $9.77 \%$ moisture, $23.72 \%$ protein, $6.49 \%$ crude fat, $12.48 \%$ crude fiber and $7.79 \%$ of Ash content. These depicted results are in agreement with Sengev et al. (2013). Higher content of Protein, crude fiber, crude fat and Ash in moringa leaves depicted that it could be useful fortificant.

Table 1 Proximate Composition of Whole Wheat Flour and Moringa oleifera Leaves Powder

\begin{tabular}{lcc}
\hline Parameters (\%) & Whole Wheat Flour & $\begin{array}{c}\text { Moringa Leaves } \\
\text { Powder }\end{array}$ \\
\hline Moisture (\%) & $10.75 \pm 0.299$ & $9.77 \pm 0.537$ \\
\hline Ash (\%) & $1.70 \pm 0.032$ & $7.79 \pm 0.756$ \\
\hline Crude Fat (\%) & $1.42 \pm 0.035$ & $6.49 \pm 0.170$ \\
\hline Crude Protein (\%) & $13.84 \pm 0.343$ & $23.72 \pm 0.187$ \\
\hline Crude Fiber (\%) & $1.67 \pm 0.378$ & $12.48 \pm 0.802$ \\
\hline
\end{tabular}

The values are the average of triplicate experiments, and presented as mean \pm standard error of mean 
The depicted result of moringa oleifera leaves powder for current study were in the range as demonstrated by Mouminah, (2015).

Table 2 Total Phenolic, Flavonoids and Antioxidant Activity of Whole Wheat Flour and Moringa oleifera leaves powder

\begin{tabular}{lccc}
\hline Sample & $\begin{array}{c}\text { TPC }(\mathbf{m g} \\
\text { GAE/g) }\end{array}$ & $\begin{array}{c}\text { TFC (mg } \\
\text { CE/g) }\end{array}$ & $\begin{array}{c}\text { Antioxidant } \\
\text { Activity } \\
\text { DPPH }(\%)\end{array}$ \\
\hline Whole Wheat Flour & $0.73 \pm 0.049$ & $0.37 \pm 0.05$ & $65.19 \pm 2.837$ \\
\hline Moringa Leaves Powder & $88.63 \pm 1.90$ & $30.86 \pm 0.82$ & $89.27 \pm 2.69$ \\
\hline Minerals (mg/100g) & Whole Wheat Flour & $\begin{array}{c}\text { Moringa Leaves } \\
\text { Powder }\end{array}$ \\
\hline Sodium (Na) & $1.24 \pm 0.06$ & $12.83 \pm 0.67$ \\
\hline Potassium (K) & $89.48 \pm 1.02$ & $1295.37 \pm 3.02$ \\
\hline Magnesium $(\mathrm{Mg})$ & $67.70 \pm 0.34$ & $211.92 \pm 1.50$ \\
\hline Iron (Fe) & $2.09 \pm 0.14$ & $7.37 \pm 0.14$ \\
\hline Zinc (Zn) & $1.01 \pm 0.10$ & $6.32 \pm 0.34$ \\
\hline Copper $(\mathrm{Cu})$ & $1.17 \pm 0.21$ & $6.3 \pm 0.10$ \\
\hline Manganese $(\mathrm{Mn})$ & $1.12 \pm 0.12$ & $8.67 \pm 0.12$ \\
\hline
\end{tabular}

Whole wheat flour and moringa leaves powder were analyzed for Total phenolic acid (TPC), Total Flavonoid content and for antioxidant activity. The depicted result showed that moringa leaves contained higher TPC and TFC content as showed in the table (2) whole wheat flour contained $0.73 \mathrm{mg} \mathrm{GAE} / \mathrm{g}$ of extract and moringa leaves powder contained $88.63 \mathrm{GAE} / \mathrm{g}$ of extract. These results were in accordance with those described by Yang et al. (2006). Similar situation in the case of Total flavonoid content TFC as whole wheat flour contained $0.37 \mathrm{mg}$ $\mathrm{CE} / \mathrm{g}$ of extract. These findings are in accordance with different researchers, as $\mathbf{L i}$ et al. (2015) reported that whole wheat flour had $0.27 \mathrm{mg} \mathrm{CE} / \mathrm{g}$ of extract of TFC While Charoensin (2014) used two different solvents for extraction from MOLP and their results for TFC ranged from 35-65 mg/g extract. Both samples were analyzed for Antioxidant activity and moringa leaves showed higher antioxidant activity percentage. Moyo et al. (2012) observed the antioxidant activity of moringa oleifera leaves powder and their results are in the range of current study.

\section{Minerals Content}

Data presented in table (3) showed the minerals content of whole wheat flour (WWF) and moringa leaves powder (MOLP) from the depicted result it could be noticed that Moringa leaves powder contained higher level of mineral than whole wheat flour as the depicted values for $\mathrm{Na}, \mathrm{K}, \mathrm{Mg}, \mathrm{Fe}, \mathrm{Zn}, \mathrm{Cu}, \mathrm{Mn}$ ware 1.24 , $89.48,67.70,2.09,1.01,1.17,1.12 \mathrm{mg} / 100 \mathrm{~g}$ for wheat flour and 12.83, 1295.37, $211.92,7.37,6.32$. 6.3, $8.7 \mathrm{mg} / 100 \mathrm{~g}$ for moringa leaves powder respectively. The depicted results are in agreement with Sengev $\boldsymbol{e t}$ al. (2013) as they analyzed both wheat flour and moringa leaves powder.

Table 3 Mineral Content of Whole Wheat Flour and Moringa oleifera Leaves Powder

\section{Pasting Properties of whole Wheat flour and Moringa leaves powder blend}

Pasting properties are of great importance because it helps to determine the extent of its use. The result of pasting properties is shown in table (4). The pasting temperature of all treatments ranged from $70.90{ }^{\circ} \mathrm{C}$ to $72.60{ }^{\circ} \mathrm{C}$. Blend consist of $100 \%$ whole wheat flour showed higher temperature. As the level of moringa leaves powder increased in the blend the pasting temperature decreased gradually, significance temperature difference was observed among the treatment except $T_{2}$ and $T_{3}$. It indicates that gelatinization of starch granules occurs at different temperature, if moringa powder level increased than the gelatinization temperature will be decreased.

Measure of cooking time is called peak time. The resulted values ranged from 4.90 to 6.49 mint, the blend $\mathrm{T}_{0}$ which consist of $100 \%$ whole wheat flour had maximum peak time. The inclusion of moringa led to significant reduction in peak time as shown in table (4) $\mathrm{T}_{4}$ that consist of $80 \% \mathrm{WWF}$ and $20 \%$ MOLP had minimum peak time. Significance difference was observed for peak time in all treatments, it is clear indicate that wheat flour blend whit higher moringa leaves powder will cook faster due to lower starch portion contained in moringa leaves powder.

Table 4 Pasting Properties of Whole Wheat Flour and Moringa oleifera Leaves Powder Blend

\begin{tabular}{|c|c|c|c|c|c|c|c|}
\hline Blend & $\begin{array}{c}\text { Pasting } \\
\text { Temperature } \\
\left({ }^{\circ} \mathrm{C}\right)\end{array}$ & $\begin{array}{l}\text { Peak Time } \\
\text { (Mint) }\end{array}$ & $\begin{array}{c}\text { Peak Viscosity } \\
\text { (RVU) }\end{array}$ & $\begin{array}{c}\text { Final Viscosity } \\
\text { (RVU) }\end{array}$ & $\begin{array}{c}\text { Through } \\
\text { (RVU) }\end{array}$ & $\begin{array}{l}\text { Break Down } \\
\text { Viscosity } \\
\text { (RVU) }\end{array}$ & $\begin{array}{c}\text { Set Back } \\
\text { Viscosity } \\
\text { (RVU) }\end{array}$ \\
\hline $\mathrm{T}_{0}$ & $72.62 \pm 0.025^{\mathrm{a}}$ & $6.49 \pm 0.10^{\mathrm{a}}$ & $2597.0 \pm 8.62^{\mathrm{a}}$ & $3392.3 \pm 4.93^{\mathrm{a}}$ & $2096.3 \pm 7.02^{\mathrm{a}}$ & $501.00 \pm 7.02^{\mathrm{c}}$ & $1296 \pm 4.58^{\mathrm{a}}$ \\
\hline $\mathrm{T}_{1}$ & $71.54 \pm 0.06^{\mathbf{b}}$ & $5.76 \pm 0.09^{\mathbf{b}}$ & $1665.3 \pm 6.50^{\mathbf{b}}$ & $2066.7 \pm 5.50^{\mathbf{b}}$ & $997.7 \pm 8.08^{\mathbf{b}}$ & $667.67 \pm 8.08^{\mathrm{a}}$ & $1069 \pm 8.10^{\mathrm{b}}$ \\
\hline $\mathrm{T}_{2}$ & $71.15 \pm 0.04^{\mathrm{c}}$ & $5.29 \pm 0.03^{\mathbf{c}}$ & $1125.3 \pm 8.73^{\mathrm{c}}$ & $1256.3 \pm 8.08^{\mathrm{c}}$ & $552.7 \pm 5.50^{\mathrm{c}}$ & $572.67 \pm 5.50^{\mathbf{b}}$ & $703.7 \pm 7.63^{\mathrm{c}}$ \\
\hline $\mathrm{T}_{3}$ & $71.08 \pm 0.07^{\mathbf{c}}$ & $5.16 \pm 0.03^{\mathrm{c}}$ & $1113 \pm 9.60^{\mathrm{c}}$ & $987.0 \pm 4.00^{\mathrm{d}}$ & $469 \pm 4.00^{\mathrm{d}}$ & $656.33 \pm 4.00^{\mathrm{c}}$ & $518 \pm 6.08^{\mathrm{d}}$ \\
\hline $\mathrm{T}_{4}$ & $70.90 \pm 0.03^{\mathrm{d}}$ & $4.90 \pm 0.03^{\mathrm{d}}$ & $854.33 \pm 9.07^{\mathrm{d}}$ & $570.7 \pm 6.02^{\mathrm{e}}$ & $262.7 \pm 6.02^{\mathrm{e}}$ & $591.67 \pm 6.02^{\mathrm{b}}$ & $308 \pm 5.00^{\mathrm{e}}$ \\
\hline
\end{tabular}

Values carrying same letters are non-significantly with each other $(\mathrm{P}<0.05)$ while having different letters are significant. Where $\mathrm{T}_{0}=\mathrm{WWF} 100 \%, \mathrm{~T}_{1}=\mathrm{WWF} 95 \%+\mathrm{MOLP} 5 \%, \mathrm{~T}_{2}=\mathrm{WWF}$ $90 \%+$ MOLP 10\%, T3= WWF 85\% + MOLP 15\%, $\mathrm{T}_{4}=\mathrm{WWF} 80 \%+$ MOLP 20\% WWF: Whole Wheat Flour, MOLP: Moringa oleifera Leaves Powder

Peak viscosity is referred as the water holding capacity of starches, normally it is assumed that the quality of final product is effected by the peak viscosity (Maziya et al., 2004). The highest peak viscosity was recorded in $T_{0}(100 \%$ whole wheat flour) that was $2597 \mathrm{RVU}$ and the lowest value $854.33 \mathrm{RVU}$ was observed in $\mathrm{T}_{4}(80 \%$ whole wheat flour and $20 \%$ moringa oleifera leaves powder). The decreased peak viscosity showed the tendency of the sample to be more resistant against mechanical fragmentation. This is also evident from the values of breakdown viscosity. Breakdown viscosity (BV) is referred as the difference between Peak and Trough viscosity. BV is the index of stability for swallon starch granules to break when held at higher temperature with continues shearing. The stage where reordering of starch granules occurs after cooling is called Setback viscosity. It is tendency of starch to become more firm. The resulted setback viscosity ranged between 308 to 1296 RVA with the highest value recorded in $\mathrm{T}_{0}(100 \%$ whole wheat flour) and the lowest observed value in $\mathrm{T}_{4}(80 \%$ whole wheat flour and $20 \%$ Moring oleifera leaves powder). The inclusion of moringa leaves powder gives non cohesive paste, which indicates that such kind of starches have low tendency towards reordering of starch. It shows that blend with $100 \%$ wheat flour give higher tendency towards reordering of starch due to high setback viscosity.

Final viscosity ranges between 570.7 to $3392.3 \mathrm{RVU}$. It was observed that by the incorporation of moringa leaves powder the final viscosity decreased gradually. Through is that point at which the sample is subjected at constant temperature and shear stress. The starch gel will be more stable if the through value will lower. The observed values for through viscosity were 262.7 to 2096.3 RVA, lower value was observed in the blend with maximum moringa leaves powder, which depict that $\mathrm{T}_{4}$ blend will constitute more stable starch gel during cooking. Similar trend of pasting properties ware observed by Chinma et al. (2014) in their research. The trend is also in agreement with the study of Badejo et al (2017) they worked on the composite flour blend of moringa leaves powder and plantain flour and got similar trend as current study.

Effect of Moringa oleifera leaves Supplementation on Mineral Composition of Chapattis (Unleavened Flat Bread)

Mineral content of moringa supplemented chapattis are presented in table (5). It was observed that there is significant increase in mineral content by increasing the level of moringa leaves powder. Moringa supplemented chapattis were analyzed for $\mathrm{Na}, \mathrm{K}, \mathrm{Mg}, \mathrm{Zn}, \mathrm{Fe}, \mathrm{Cu}$ and $\mathrm{Mn}$ with maximum values recorded in $\mathrm{T}$ (80\% Whole wheat flour and $20 \%$ Moringa oleifera leaves powder) as 7.61 , 286.07, 147.75, 4.78, 4.09 and 5.12 the minimum values were recorded in $\mathrm{T}_{0}$ (100\% Whole Wheat flour) as $1.26,89.46,67.87,1.51,2.13,2.11$ and 1.13 $\mathrm{mg} / 100 \mathrm{~g}$ respectively. As the supplementation level of moringa leaves increased the mineral level increased gradually (table 5).

The results of present study are strongly supported by Sengev $\boldsymbol{e t}$ al. (2013) they observed the effect of moringa leaves powder on the quality of bread. The results of present study are also in accordance with Karim et al. (2013). Their results indicate that by increasing the level of moringa powder in blend the copper content also increased 
Table 5 Mineral Content of Moringa oleifera Leaves Supplemented Chapattis (mg/100g)

\begin{tabular}{lccccccc}
\hline Treatment & $\mathbf{N a}$ & $\mathbf{K}$ & $\mathbf{M g}$ & $\mathbf{Z n}$ & $\mathbf{F e}$ & $\mathbf{C u}$ & $\mathbf{M n}$ \\
\hline $\mathrm{T}_{0}$ & $1.26 \pm 0.02^{\mathrm{e}}$ & $89.46 \pm 0.58^{\mathrm{e}}$ & $67.87 \pm 2.12^{\mathrm{e}}$ & $1.51 \pm 0.01^{\mathrm{d}}$ & $2.13 \pm 0.05^{\mathrm{e}}$ & $2.11 \pm 0.09^{\mathrm{d}}$ & $1.13 \pm 0.02^{\mathrm{e}}$ \\
\hline $\mathrm{T}_{1}$ & $2.82 \pm 0.05^{\mathrm{d}}$ & $145.60 \pm 2.10^{\mathrm{d}}$ & $84.44 \pm 0.12^{\mathrm{d}}$ & $2.80 \pm 0.15^{\mathrm{c}}$ & $2.49 \pm 0.01^{\mathrm{d}}$ & $2.48 \pm 0.13^{\mathrm{d}}$ & $2.61 \pm 0.08^{\mathrm{d}}$ \\
\hline $\mathrm{T}_{2}$ & $4.37 \pm 0.06^{\mathbf{c}}$ & $195.70 \pm 2.80^{\mathrm{c}}$ & $95.95 \pm 1.42^{\mathrm{c}}$ & $3.64 \pm 0.62^{\mathrm{bc}}$ & $2.83 \pm 0.05^{\mathrm{c}}$ & $3.55 \pm 0.10^{\mathrm{c}}$ & $3.55 \pm 0.04^{\mathrm{c}}$ \\
\hline $\mathrm{T}_{3}$ & $5.92 \pm 0.05^{\mathrm{b}}$ & $237.90 \pm 1.99^{\mathrm{b}}$ & $124.77 \pm 4.43^{\mathrm{b}}$ & $4.19 \pm 0.06^{\mathrm{ab}}$ & $3.17 \pm 0.06^{\mathrm{b}}$ & $4.43 \pm 0.21^{\mathrm{b}}$ & $4.54 \pm 0.08^{\mathrm{b}}$ \\
\hline $\mathrm{T}_{4}$ & $7.61 \pm 0.07^{\mathrm{a}}$ & $286.07 \pm 1.45^{\mathrm{a}}$ & $147.75 \pm 2.19^{\mathrm{a}}$ & $4.78 \pm 0.31^{\mathrm{a}}$ & $4.09 \pm 0.20^{\mathrm{a}}$ & $5.12 \pm 0.18^{\mathrm{a}}$ & $5.78 \pm 1.00^{\mathrm{a}}$ \\
\hline \multicolumn{7}{l}{ Values carrying same letters are non-significantly with each other $(\mathrm{P}<0.05)$ while having different letters are significant. Where $\mathrm{T}_{0}=\mathrm{WWF} 100 \%, \mathrm{~T}_{1}=\mathrm{WWF}$}
\end{tabular}

$95 \%+$ MOLP 5\%, $\mathrm{T}_{2}=\mathrm{WWF} 90 \%+\mathrm{MOLP} 10 \%, \mathrm{~T} 3=\mathrm{WWF} 85 \%+\mathrm{MOLP} 15 \%, \mathrm{~T}_{4}=\mathrm{WWF} 80 \%+\mathrm{MOLP} 20 \%$, WWF: Whole Wheat Flour, MOLP:

\section{Moringa oleifera Leaves Powder}

By using different green leafy vegetables in bun, biscuits, cookies and bread the improvement in mineral content have also been reported (Dachana et al. 2010) Significance improvement $(\mathrm{P}<0.05)$ in $\mathrm{Na}, \mathrm{K}, \mathrm{Mg}, \mathrm{Zn}, \mathrm{Fe}, \mathrm{Cu}$ and was observed by supplementation of moringa leaves.

Effect of Moringa oleifera leaves Supplementation on Total Phenolic content, Total Flavonoid content and Antioxidant activity

Chapattis supplemented with moringa leaves powder at different level also analyzed for TPC, TFC, and antioxidant activity percentage and significant improvement was reported by the inclusion of Moringa oleifera leaves powder in total phenolic content, Total flavonoid content and antioxidant activity. TPC of control chapattis was $0.75 \mathrm{mg} \mathrm{GAE} / \mathrm{g}$ extract and showed significant increase $(\mathrm{P}<0.05)$ by supplementation with moringa leaves as $\mathrm{T}_{4}(80 \%$ Whole wheat flour and 20\% Moringa leaves powder) showed $8.38 \mathrm{mg} \mathrm{GAE} / \mathrm{g}$ extract (table 6).

Table 6 Total Phenolic, Flavonoids and Antioxidant Activity of Chapattis Supplemented with Moringa oleifera leaves powder

\begin{tabular}{lccc}
\hline Treatment & TPC $(\mathbf{m g}$ GAE/g) & $\begin{array}{c}\text { TFC }(\mathbf{m g} \\
\text { CE/g) }\end{array}$ & $\begin{array}{c}\text { Antioxidant } \\
\text { Activity DPPH } \\
(\%)\end{array}$ \\
\hline $\mathrm{T}_{0}$ & $0.75 \pm 0.10^{\mathrm{e}}$ & $0.38 \pm 0.10^{\mathrm{e}}$ & $64.32 \pm 1.17^{\mathrm{d}}$ \\
\hline $\mathrm{T}_{1}$ & $2.30 \pm 0.13^{\mathrm{d}}$ & $1.36 \pm 0.13^{\mathrm{d}}$ & $67.92 \pm 1.23^{\mathbf{c d}}$ \\
\hline $\mathrm{T}_{2}$ & $4.82 \pm 0.18^{\mathrm{c}}$ & $2.14 \pm 0.16^{\mathrm{c}}$ & $71.25 \pm 1.32^{\mathbf{b c}}$ \\
\hline $\mathrm{T}_{3}$ & $6.41 \pm 0.35^{\mathrm{b}}$ & $2.98 \pm 0.26^{\mathrm{b}}$ & $75.08 \pm 2.16^{\mathrm{b}}$ \\
\hline $\mathrm{T}_{4}$ & $8.38 \pm 0.35^{\mathrm{a}}$ & $3.66 \pm 0.29^{\mathrm{a}}$ & $80.52 \pm 2.24^{\mathrm{a}}$ \\
\hline
\end{tabular}

Values carrying same letters are non-significantly with each other $(\mathrm{P}<0.05)$ while having different letters are significant. Where $\mathrm{T}_{0}=\mathrm{WWF} 100 \%, \mathrm{~T}_{1}=\mathrm{WWF}$ $95 \%+$ MOLP 5\%, T $2=$ WWF $90 \%+$ MOLP $10 \%$, T3= WWF $85 \%+$ MOLP $15 \%, \mathrm{~T}_{4}=\mathrm{WWF} 80 \%+$ MOLP $20 \%$ WWF: Whole Wheat Flour, MOLP: Moringa oleifera Leaves Powder

Similar trend was observed in Total Flavonoid content, control sample showed $0.38 \mathrm{mg} \mathrm{CE} / \mathrm{g}$ Extract and significant enhancement $(\mathrm{P}<0.05)$ observed with values $3.66 \mathrm{mg} \mathrm{CE} / \mathrm{g}$ extract. wide variation was observed in DPPH scavenging activity of Chapattis sample control sample showed $64.32 \%$ and by the addition of moringa oleifera leaves powder the antioxidant percentage increase significantly $(\mathrm{P}<0.05)$. As the maximum value was observed in $\mathrm{T}_{4}$ which is 80.52 $\%$. Different studies showed increase of antioxidant activity, TPC, and TFC content. Reddy et al. (2005) evaluate the antioxidant activity of some plan extract and utilized in biscuits, their result showed that moringa possess higher antioxidant activity as they evaluate the biscuit incorporated with the extract and they revealed that biscuit sample with moringa leaves extract showed the minimum peroxide value and free fatty acids due to stronger antioxidant activity of moringa leaves.

\section{Effect of Moringa leaves supplementation of the Sensory Attributes of chapattis}

Sensory evaluation was done by using 9-point Hedonic scale, the Mean score of sensory attributes of chapattis are presented in Figure 1. It was observed that preference decreased in all sensory attributes as level of Moringa oleifera leaves powder increased. Significant increase $(\mathrm{P}<0.05)$ difference was observed in Color, aroma, taste and overall Acceptability. Preferences of these attributes decreased as the increase in the percentage of Moringa oleifera leaves powder. The decrease in the preference or like ness is due to the sharp Herbal flavor of leaves. The decrease in taste, aroma and overall acceptability means panelist did not like the chapattis supplemented with moringa powder. The score of sensory attributes till $\mathrm{T}_{2}(90 \%$ Whole wheat flour and $10 \%$ Moringa oleifera leaves powder) was in acceptable range. Different flavoring agent could be used to mask the sharp flavor of moringa powder which can help to improve the taste and overall acceptability of chapattis.

Mouminah (2015) used three different level of moringa oleifera leaves powder in cookies as 5,10,15\% the reported results showed similar trend in organoleptic attributes of cookies as in current study. Kolawole et al. (2013) reported 6.8, 5.9, and 5.3 score for aroma to moringa leaves fortified cake having 8,12 , and $16 \%$ MOLP. Those results were in accordance with present study.

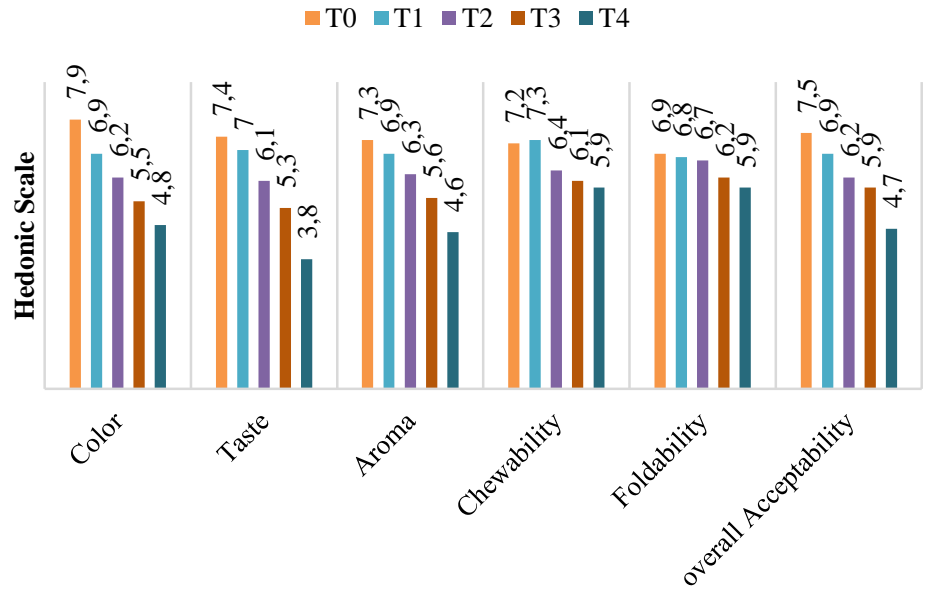

Parameters

$\mathrm{T}_{0}=\mathrm{WWF} 100 \%, \mathrm{~T}_{1}=\mathrm{WWF} 95 \%+\mathrm{MOLP} 5 \%, \mathrm{~T}_{2}=\mathrm{WWF} 90 \%+\mathrm{MOLP} 10 \%$ T3= WWF 85\% + MOLP 15\%, T $=$ WWF 80\% + MOLP 20\% WWF: Whole Wheat Flour, MOLP: Moringa oleifera Leaves Powder.

Figure 1 Sensory Attributes of Moringa oleifera leaves supplemented chapattis

\section{CONCLUSION}

The characterization of moringa leaves explored results of protein, fiber, fat and micronutrients particularly minerals and higher antioxidant activity strengthen the hypothesis that moringa is efficient supplementation source. Similarly, the consequences of analysis for mineral and antioxidants activity for chapattis as $\mathrm{T}_{4}$ (80\% Whole wheat flour and $20 \%$ Moringa oleifera leaves powder) possessed the maximum mineral content as well as antioxidant activity among all other treatment which is evident of its great potential against micronutrients' deficiency. As mineral content of MOLP was significantly higher than WWF and also the resulted chapattis with greater proportion of MOLP noticed to have more minerals so this formulation is proved to be significant for value addition of chapattis under nutritional point of view. Results for pasting properties of composite flour blend also supported that the final developed chapatti will have the soft texture that is commonly acceptable by consumers. Sensory evaluation results depicted better taste and aroma at 5\% and 10\% Moringa oleifera leaves supplementation. Chapattis with $10 \%$ Moringa oleifera leaves supplementation was recommended.

\section{REFERENCES}

AACC. 2000. Approved Methods of American Association of cereal Chemists Am. Assoc. Cereal Chem. Inc., St. Paul, MN, USA

ANJUM, F.M., BUTT, M.S., AHMAD, N., AHMAD, I. 2002. Phytate and mineral content in different milling fractions of some Pakistani spring wheats International Journal of Food Science \& Technology, 37, 13-17. https://doi.org/10.1046/j.1365-2621.2002.00540.x .

ANWAR, F., BHANGER, M. 2003. Analytical characterization of Moringa oleifera seed oil grown in temperate regions of Pakistan. Journal of Agricultural and Food Chemistry, 51, 6558-6563. https://doi.org/10.1021/jf0209894.

ANWAR, F., LATIF, S. ASHRAF, M., GILANI, A.H. 2007. Moringa oleifera: a food plant with multiple medicinal uses. Phototherapy Research, 21, 17 25. https://doi.org/10.1002/ptr.2023

AOAC. 2006. Official Methods of Analysis of Association of Official Analytical Chemists International. In: Horwitz, W. (Ed.), $18^{\text {th }}$ Ed. AOAC Press, and Arlington, VA, USA. 
BADEJO, A.A., OSUNLAKIN, A.P., FAMAKINWA, A., IDOWU, A.O., FAGBEMI, T.N. 2017. Analyses of dietary fibre contents, antioxidant composition, functional and pasting properties of plantain and Moringa oleifera composite flour blends. Cogent Food and Agriculture, 3, 78-87. https://doi.org/10.1080/23311932.2017.1278871.

BUTT, M., ANJUM, F., ALI, A. REHMAN, A. 1997. Milling and baking properties of spring wheat. Journal of Agriculture Research, 35, 403412. https://doi.org/10.1111/j.1745-4549.2009.00405.x.

CHINMA, C., ABU, J., AKOMA, S. 2014. Effect of Germinated Tigernut and Moringa Flour Blends on the Quality of Wheat- Based Bread. Journal of Food Processing and Preservation, 38, 721-727. https://doi.org/10.1111/jfpp.12023.

Dachana, K., Rajiv, J., Indrani, D., Prakash, J. 2010. Effect of dried Moringa (Moringa oleifera Lam) leaves on rheological, microstructural, nutritional, textural and organoleptic characteristics of cookies. Journal of Food Quality, 33, 660-677. https://doi.org/10.1111/j.1745-4557.2010.00346.x.

IQBAL, S., BHANGER, M. 2006. Effect of season and production location on antioxidant activity of Moringa oleifera leaves grown in Pakistan. Journal of Food Composition and Analysis, 19, 544-551. https://doi.org/10.1016/j.jfca.2005.05.001

KADAM, M., R. SALVE, MEHRAJFATEMA, Z., MORE, S. 2012 Development and evaluation of composite flour for Missi roti/chapatti. Journal of Food Processing and Technology, 3, 2-8. https://doi.org/10.4172/21577110.1000134

KARIM, O.R., KAYODE, R.M.O, OYEYINKA, S., OYEYINKA, A.T. 2013 Proximate, mineral and sensory qualities of 'Amala' prepared from yam flour fortified with moringa leaf powder. Food Science and Quality Management, 12 10-22. https://doi.org/10.4038/jas.v12i2.8227.

KIM, M.J., KIM, S.S. 2016. Antioxidant and antiproliferative activities in immature and mature wheat kernels. Food Chemistry, 196, 638-45. https://doi.org/10.1016/j.foodchem.2015.09.095.

KOLAWOLE, F.L., BALOGUN, M.A., OPALEKE, D.O. AMALI, H.E. 2013. An evaluation of nutritional and sensory qualities of wheat-moringa cake. Agro Search, 13, 87-94. https://doi.org/10.4314/agrosh.v13i1.9.

Mahmood, K.T., T. Mugal and I.U. Haq. 2010. Moringa oleifera: A natural gift-a review. Journal of Pharmaceutical Sciences and Research, 1, 775-781

MAZIYA-DIXON, B. A., DIXON, G. O., ADEBOWALE, A. A. 2004. Targeting different end uses of cassava: Genotypic variations for cyanogenic potentials and pasting properties. International Journal of Food Science and Technology, 42, 969-976. https://doi.org/10.1111/j.1365-2621.2006.01319.x.

MBIKAY, M. 2012. Therapeutic potential of Moringa oleifera leaves in chronic hyperglycemia and dyslipidemia: a review. Frontiers in Pharmacology, 3, 1-12 MEILGARD, M.M., CIVILLE, G.V., CARR , T. 2007. Sensory evaluation techniques. 4th Ed. CRC Press, New York, NY, USA.

MENSOR, L.I., MENEZES, F.S., LEITAO, G.G., REIS, A.S., DOS SANTOS, T., COUBE, C.S., LEITAO, S.G. 2001. Screening of Brazilian plant extracts for antioxidant activity by the use of DPPH free radical method. Phototherapy Research, 15, 127-130. https://doi.org/10.1002/ptr.687.

MOUMINAH, H.H.S. 2015. Effect of dried Moringa oleifera leaves on the nutritional and organoleptic characteristics of cookies. Alexandria Science Exchange Journal, 36, 297-302. https://doi.org/10.21608/asejaiqjsae.2015.2934. MOYO, B., MASIKA, P.J., HUGO, A., MUCHENJE, V. 2011. Nutritional characterization of moringa (Moringa oleifera Lam.) leaves. African Journal of Biotechnology, 10, 12925-12933. https://doi.org/10.5897/ajb10.1599.

OWUSU, D., ELLIS, W.O., ODURO I. 2008. Nutritional potential of two leafy vegetables: Moringa oleifera and Ipomoea batatas leaves. Scientific Research and Essay, 3, 57-60.

REBECCA, H., SHARON, M., ARBAINSYAH, A., LUCIENNE, D. 2006. Moringa oleifera: medicinal and socio-economic uses. International course on economic botany. National Herbarium Leiden, Netherlands, 4, 2-6. https://doi.org/10.18052/www.scipress.com/ilns.20.85.

REDDY, V., UROOJ, A., KUMAR, A. 2005. Evaluation of antioxidant activity of some plant extracts and their application in biscuits. Food Chemistry, 90, 317 321. https://doi.org/10.1016/j.foodchem.2004.05.038.

SENGEV, A.I., ABU, J.O., GERNAH, D.I. 2013. Effect of Moringa oleifera leaf powder supplementation on some quality characteristics of wheat bread. Food and Nutrition Sciences, 4, 270-275. https://doi.org/10.4236/fns.2013.43036.

SIDDHURAJU, P., BECKER, K. 2003. Antioxidant properties of various solvent extracts of total phenolic constituents from three different agroclimatic origins of drumstick tree (Moringa oleifera Lam.) leaves. Journal of Agricultural and Food Chemistry, 51, 2144-2155. https://doi.org/10.1021/jf020444+ .

SINGH, G., KAWATRA, A. 2006. Development and nutritional evaluation of recipes prepared using fresh and dried amaranthus leaves. Journal of Food Science and Technology, 43, 509-511

STEEL, R.G.D., TORRIE, J.H., DICKY, D.A. 1997. Principles and Procedures of Statistics: A Biometrical Approach. ${ }^{\text {rd }}$ Ed. MccGraw Hill Book Co. Inc., New York, USA.

SUN, J., LIANG, F. BIN, Y., LI, P., DUAN, C. 2007. Screening non-colored phenolic in red wines using liquid chromatography/ ultraviolet and mass spectrometry/mass spectrometry libraries. Molecules, 12, 679693. https://doi.org/10.3390/12030679. 